\title{
Corrosion Resistance of Plasma Nitrided and Nitrocarburized 42CrMo4 Steel
}

\section{David Kusmic, Doan Van Thanh}

Department of Mechanical Engineering, Faculty of Military Technology, University of Defence, Kounicova 65,66210 Brno, Czech Republic, E-mail: david.kusmic@unob.cz, thanhvan.doan@unob.cz

This article deals with comparison of corrosion resistance of $42 \mathrm{CrMo4}$ steel used for breech mechanism in the armament production. Increasing of demands on materials used for armament production and in other industrial application leads to the innovation of technologies in the field of surface treatment especially wear resistance, surface hardness, running-in properties and corrosion resistance. For the evaluation of experimental NSS corrosion resistance tests samples of 42CrMo4 steel were compared with plasma nitrided and nitrocarburized one. Individual 42CrMo4 steel samples were subsequently metallographically evaluated and characterized by hardness and microhardness measuring. The results and comparison of corrosion resistance of not-surface treated steel samples with plasma nitrided and nitrocarburized showed significant differences of corrosion rate. Due to different plasma nitriding conditions, there are corrosion resistance differences evident between the plasma nitrided steel samples as well. The corrosion resistance evaluation is supplemented by the surface corrosion-free surfaces evaluation using the laser confocal microscopy.

Keywords: Corrosion, plasma nitriding, nitrocarburizing, surface layer

\section{Acknowledgements}

The paper has been prepared thanks to the support of the project The Development of Technologies, Design of Firearms, Ammunition, Instrumentation, Engineering of Materials and Military Infrastructure "VÝZBROJ (DZRO K201)." and "Surface technology in applications special techniques SV16-216."

\section{References}

[1] STUDENÝ, Z. (2015). Analysis of the Influence of Initiating Inclusions on Fatigue Life of Plasma Nitrided Steels. In: Manufacturing Technology, Vol. 15, No. 1, pp. 99 - 105.

[2] MANIEE, A., MAHBOUBI, F., SOLEIMANI, R. (2014). The study of tribological and corrosion behavior of plasma nitride 34CrNiMo6 steel under hot and cold wall conditions. In: Journal Materials and Design, Vol. 60, pp. $599-604$.

[3] DOAN, T., V., KUSMIČ, D., POSPICHAL, M. (2015). Surface Treatment Technologies for Wear Resistance Increasing of 42CrMo4 Steel. In: Manufacturing Technology, Vol. 15, No. 3, pp. 303 - 307.

[4] PYE, D. (2003). Practical nitriding and ferritic nitrocarburizing, pp. 31 - 36, ASM International, Materials Park, Ohio.

[5] NOVÁ, I., MACHUTA, J. (2016). Monitoring of the Duffusion Process during Carburizing Automotive Steel Parts, In: Manufacturing Technology, Vol. 16, No. 1, pp. 225 - 230.

[6] VALÁŠEK, P. (2015). Influence of Surface Treatment of Steel Adherends on Shear Strength of Filled Resins, In: Manufacturing Technology, Vol. 15, No. 3, pp. 468 - 474.

[7] POKORNÝ, Z., HRUBÝ, V., STUDENÝ, Z. (2016). Effect of nitrogen on surface of layers, In: Metallic Materials, Vol. 54, No. 2, pp. 119 - 124.

[8] NIKOLUSSI, M., LEINEWEBER, A., BISCHOFF, E., MITTEMEIJER, E. J. (2007). Examination of phase transformations in the system Fe-N-C by means of nitrocarburising reactions and secondary annealing experiments, the $\alpha+\varepsilon$ two-phase equilibrium. In: Journal Material Research, Vol. 98, No. 11, pp. 1086 - 1092.

[9] DONG-CHERNG, W. (2009). Plasma nitriding of plastic mold steel to increase wear and corrosion properties. In: Surface\&Coatings Technology, Vol. 204, pp. 511 - 519.

[10] BASU, A., MAJUMBAR, A., ALPHONSA, J. D., MUKHERJEE, MANNA, J. I. (2008). Corrosion resistance improvement of high carbon low alloy steel by plasma nitriding. In: Journal Materials Letters, Vol. 62, pp. 3117 -3120 .

[11] LI, Y., WANG, L., ZHANG, D., SHEN, L. (2010). Improvement of corrosion resistance of nitrided low alloy steel by plasma post-oxidation. In: Journal Applied Surface Science, Vol. 256, Issue 13, pp. 4149 - 4152. 
[12] KUSMIČ, D. DOBROCKÝ, D. (2015). Corrosion Resistance of Plasma Nitrided Structural Steels. In: Manufacturing Technology, Vol. 15, No. 1, pp. 64-69.

[13] EBRAHIMI, M., HEYDARZADEH, S. M, MAHBOUDI, F. (2010). Effect of plasma nitriding temperature on the corrosion behavior of AISI 4140 steel before and after oxidation. In: Journal Surface \& Coatings Technology, Vol. 205, pp. 261 - 266.

[14] MARUŠIĆ, K., OTMAČIĆ, H., LANDEK, D., CAJNER, F., STUPNIŠEK-LISAC, E. (2006). Modification of carbon steel surface by the Tenifer ${ }^{\circledR}$ process of nitrocarburizing and post-oxidation. In: Journal Surface \& Coatings Technology, Vol. 201, pp. 3415 - 3421.

[15] WU, J., LIU, H., LI, J., YANG, X., HU, J. (2015). Enhancement of corrosion resistance for plasma nitride AISI 4110 steel by plain air plasma post-oxidizing. In: Journal of Alloys and Compounds, Vol. 632, pp. 397 - 401.

[16] EL-SAYED M. SHERIF (2012). Electrochemical and Gravimetric Study on the Corrosion and Corrosion Inhibition of Pure Copper in Sodium Chloride Solutions by Two Azole Derivatives. In: Journal Electrochemical Science, Vol. 7, pp. 1482 - 1495.

[17] ROTNIK, U., DOLECEK, V., VEHOVAR, L., BOZIC, S. (2006). The corrosion resistance of nitrogen-alloyed austenitic stainless steel to pitting processes under conditions of erosion corrosion. In: Metallic Materials, Vol. 44, No. 2, pp. 89-99. 